\title{
Effects of cultivation methods on some soil biological parameters of a meadow chernozem soil (Vertisols)
}

\author{
Ágnes Oláh, Zsuposné \\ Department of Agrochemistry and Soil Science, Faculty of Agricultural and Food Sciences and Environment Management, \\ Centre of Agriculture and Applied Economic Sciences, University of Debrecen, 138 Böszörményi út, H-4032 Debrecen \\ E-mail: zsuposne@agr.unideb.hu
}

Keywords: cultivation methods, conservation tillage, biological activity, enzyme activity

SUMMARY

\begin{abstract}
The effect of extended drought conditions on soil, the unfavourable cultivation technologies and the application of chemicals have been enhancing the processes of physical and biological soil degradation, so the fertility of soil is gradually declining.

The effects of two cultivation methods - traditional ploughing (TP) and conservation tillage (CT) - on the biological activity of a meadow chernozem soil were examined in a long term experiment. Different parameters of the biological activity of soil were determined. These are the numbers of total bacteria, microscopic fungi, aerobic cellulose decomposing bacteria, as well as the activities of some important soil enzymes and $\mathrm{CO}_{2}$ production.

Conservation tillage seemed to be a more favourable cultivation method for the majority of microorganisms, the activities of urease and dehydrogenase enzymes and $\mathrm{CO}_{2}$ production, compared to the traditional ploughing system. These parameters increased significantly, especially in the upper layer of conservation tillage plots. Concerning the plant cultures, the majority of microbiological parameters were higher in the soil of vetch (Vicia sativa L.) depending on the cultivation methods, so involving the pulses to the crop-rotation seems to be very important in this soil type.

According to the ninth year's results, the importance of conservation tillage as a means of protecting the soil biological activity in meadow
\end{abstract} chernozem (Vertisols) can be established; it was proven by microbiological investigations.

\section{INTRODUCTION}

Soil is the natural environment of microorganisms; they need favourable physical, chemical conditions for functioning. If these conditions are suitable, the soil biological activity and, in accordance with it, the soil fertility are good. This paper deals with the effects of cultivation methods - as the most common anthropogenic factor - on some parameters of the biological activity of a meadow chernozem soil.

Soil fertility considerably depends on the agrotechnical factors. Ecosystem productivity and stability rely in a large part on the activity of the soil microbial community, whose nutrients and energy are provided by the mineralization of organic carbon compounds. The response of microorganisms, in terms of both biomass and soil biological activity, is very high; they are influenced by the management practices and changes in natural environment. A major agricultural research priority is to sustain soil productivity and to develop better methods to monitor changes in soil physical, chemical, and biological properties affected by management (Larson et al., 1981).

Tillage temporarily aerates the soil and controls weeds, but year by year it destroys the desirable soil structure and in the long run reduces aeration. These changes occur because of the accelerated organic matter decomposition and the formation of dense impermeable tillage pans (Donahue et al., 1983). Green et al. (2007) determined the effect of three tillage methods (no-till, disk harrow, and disk plough) on soil biological activity and aggregate stability. Five different soil enzyme activities, $\mathrm{C}$ - and $\mathrm{N}$-mineralizations, organic carbon, total $\mathrm{N}$ and aggregate stability were determined. The no-till system revealed greater concentration and activities (18$186 \%$ ) than disk plough in the 0-5 cm layer of these analyses. Enzyme activities in all treatments correlated more strongly with total soil $\mathrm{N}$ than with soil organic $\mathrm{C}$ in the soil examined.

Several authors have examined the effects of different kinds of tillage on the physical, chemical and biological properties of soil belonging to different soil types. Roldan et al. (2007) examined the no-tillage system on a Vertisol. The no-till can be considered an effective management practice for carrying out sustainable agriculture under subtropical conditions, as it improves soil physical and biochemical qualities and $\mathrm{C}$ sequestration.

The availability of an element for plants and microorganisms is generally associated with organic matter content, microbial activity, and $\mathrm{pH}$. Soil biological factors that influence soil quality are reviewed. These include the size and diversity of microorganisms, and micro and macro faunal biomass. The effects of tillage, crop residues and microbial activity on soil stability, the benefits of legumes in rotation schemes and green manures are considered to be influencing factors (Bollag et al., 1996). Several papers deal with the physical, chemical and biological effects of different cultivation methods. Kandeler and Murer (1993) examined the effects of temporary grassland and conventional tillage on aggregate stability and soil microbial processes in a field trial in Austria. They stated that, firstly, temporary grassland increases microbial biomass; secondly, microorganisms produce enzymes which mineralize organic compounds, and aggregate stability increases due to the influence of microbial biomass, their activities and their by-products. After ploughing grassland, both the aggregate stability and soil microbial processes decreased rapidly. These results indicate that continuous vegetation and the activities of soil organisms are preconditions to maintain high aggregate stability. Grego et al., (1996) discussed the response of microorganisms to management practices and changes in natural environment in terms of biomass and activity. 
Their results confirm that different land uses induce great changes in soil organic matter content in a short time which have a strong influence on soil microbial biomass. Rampazzo et al. (1999) found that cultivated soil showed a decrease in soil organic matter and effective cation exchange capacity, a loss of nutrients, a reduced microbial activity, a reduction of root growth and faunal activities in the tillage horizons.

However, there has been relatively little research to document the effects of different tillage systems on soil enzymes and soil microorganisms. According to Samuel et al. (2008) no-tillage planting causes minimal soil disturbance and, combined with crop rotation, can potentially meet the goals of reducing soil degradation and improving agricultural sustainability. Soil enzyme activities can provide information on how soil management affects the soil potential to perform processes such as decomposition and nutrient cycling. No-till -in comparison with conventional tillage- resulted in significantly higher soil enzymatic activities in the $0-20 \mathrm{~cm}$ (Roldan et al., 2005) so the activity of soil enzymes can be used as an indicator of soil quality for assessing the sustainability of the agricultural ecosystem. Enzyme activity and aggregate stability showed higher sensitivity to soil management practices than physical-chemical properties.

The assessment of conservation practices requires the measurement of the changes in soil quality. However, the relatively small scale change in soil organic matter (SOM) content is a reaction to changes in tillage practice. Soil microbial biomass has been proven to be the indicator of long-term changes in SOM content (Carter, 1986; Powlson et al., 1987). Soil enzyme activities are also sensitive indicators of management-induced changes in SOM content and/or biological activity (Dick 1992; Kennedy and Papendick 1995; Bergstrom et al., 1998a). Singh et al., (2009) studied the impact of two tillage intensities (conservation tillage and conventional) on the soil microbiological properties under long-term maize-wheat crop rotation. The soil under bed planting or conventional methods revealed significantly higher dehydrogenase enzyme activity and microbial biomass carbon than the conventional tillage at all the three irrigation regimes receiving different $\mathrm{N}$-sources. Soil microbial biomass carbon was significantly higher under conservational tillage (13\%) than the conventional tillage. The application of organic N sources significantly increased the soil microbial biomass carbon (41\%) in the soils receiving the recommended dose of nitrogen as urea. This study demonstrates the positive effects of the conservation tillage method on selected biological parameters, especially, in soils receiving a combination of organic and inorganic N-sources.

In the Middle-Tisza region, in Hungary, agricultural plant cultivation is mainly determined by drought, as the average rainfall is about $150-170 \mathrm{~mm}$ in the vegetation season. The effect of the extended drought condition on soil, the uneven water supply, the unfavourable cultivation technology and the application of chemicals enhance the process of physical soil degradation.

This paper deals with effects of two different cultivation methods - traditional ploughing (TP) and conservation tillage $(\mathrm{CT})$ - on some microbiological parameters within a long term experiment in a meadow chernozem (Vertisol) soil. Different soil biological examinations were made to get to know more about the effects of the human factors on soil biological activity. In this paper we would like to present the microbiological results in two layers (0-10 and 10-20 cm) of soil under two plant cultures in the ninth-year of the experiment.

\section{MATERIALS AND METHODS}

Joining the "Programme of Experiment" at the Research Institute of Karcag, University of Debrecen, our aim was to obtain reliable data on how the different cultivation methods would influence the microbiological processes in the ninth year of a long term experiment.

Soil cultivation and utilization field trials were set up and conducted on meadow chernozem soil in 1997. In the experimental field, the effects of two types of cultivation methods - traditional ploughing (TP) and conservation tillage (CT) - on some microbiological processes were measured every year. The plants were winter wheat (Triticum aestivum L.) and vetch (Vicia sativa L.) in the ninth year. In the case of conservation tillage there was no ploughing applied, only direct sowing. Deep loosing was made in every four years. During the growing season, soil samples were taken three times a year, in spring, in early summer and autumn, from the depths of 010 and $10-20 \mathrm{~cm}$.

In the course of laboratory analyses, the total numbers of bacteria, microscopic fungi, aerobic cellulose decomposing bacteria, as well as the activity of phosphatase, urease, dehydrogenase enzymes and $\mathrm{CO}_{2}$ production were determined and evaluated.

The total numbers of soil bacteria and fungi were measured by plate dilution method, and the number of cellulose decomposing bacteria was investigated according to Pochon and Tardieux (1962). The measurement of phosphatase activity was carried out by Krámer-Erdei (cit. Szegi, 1979). Urease activity (Szegi, 1979) was based on the quantitative determination of ammonia which released from urea. The dehydrogenase enzyme activity was measured by Mersi (1996), when the INT (2-(p-iodophenyl)-3-(p-nitrophenil)-5-phenil tetrazolium chloride) reduced to INTF (iodonitro-tetrazolium formazan), and $\mathrm{CO}_{2}$ production $\left(\mathrm{CO}_{2} \mathrm{mg} / 100 \mathrm{~g} / 7\right.$ days) was measured by Jenkinson et al (1976). The measurements were carried out in fresh soil samples in four repetitions, the results were evaluated statistically by Microsoft Excel software, and the significance was studied at 5\% level. 


\section{RESULTS AND DISCUSSION}

On the basis of the mean values of the ninth year, first we would like to present the microbiological results of the traditional ploughing (TP) and the conservation tillage (CT) respectively, regarding the two plant cultures: winter wheat and vetch. Then we compare the results of the two cultivation methods in the two examined layers $(0-10$ and $10-20 \mathrm{~cm})$.

Regarding traditional ploughing, the following can be stated (Table 1):

- The total number of bacteria was higher in the wheat culture than in the vetch, especially in the upper 0-10 $\mathrm{cm}$ layer. In the 10-20 cm layer a lower bacteria number was measured in the two plants (except for one treatment), and generally, significant differences were proven between the results at $5 \%$ level.

- Regarding the quantity of microscopic fungi, higher numbers were cultured from the plots of vetch in both layers; the differences were significant in most cases.

- With reference to the aerobic cellulose decomposing bacteria, there were no significant differences between the results of the two layers in the wheat plots. As for the vetch culture, higher values were obtained in the upper layer, while in the 10-20 cm layer the bacterium number decreased significantly.

- Regarding the phosphatase activity, the most intense enzyme activity was measured in the deeper, 10-20 cm layer, but the differences were not significant.

- The leguminous vetch plant culture was favourable for urease activity in both layers, and there were significant differences between the results of the two plant cultures.

- As for dehydrogenase enzyme, significantly higher activities were measured in the upper layers, and significant differences were proven at $5 \%$ level.

- Regarding $\mathrm{CO}_{2}-$ similarly to phosphatase activity - a higher production was measured in the deeper, 10-20 $\mathrm{cm}$ layer, especially in the vetch culture; the mean value is about $17.34 \%$.

Microbiological parameters in traditional ploughing plots of the long term experiment in Karcag

Table 1 Mean values of 2006

\begin{tabular}{|c|c|c|c|c|c|c|c|}
\hline \multirow[t]{2}{*}{ Sample } & \multirow[b]{2}{*}{$\begin{array}{l}\text { Total } \\
\text { number of } \\
\text { bacteria } \\
\times 10^{6} \mathrm{cfu} \text {. } \\
\mathrm{g}^{-1} \mathrm{dwt} \\
\text { soil }\end{array}$} & \multicolumn{2}{|c|}{ Number of } & \multirow{2}{*}{$\begin{array}{l}\text { Phosphatase } \\
\text { activity } \\
\mathrm{mg} \mathrm{P}_{2} \mathrm{O}_{5} \cdot 5 \mathrm{~g}^{-} \\
{ }_{1} \mathrm{dwt} \text { soil } \\
\cdot 2 \mathrm{~h}^{-1}\end{array}$} & \multirow{2}{*}{$\begin{array}{c}\text { Urease } \\
\text { activity } \\
\mathrm{mg} \mathrm{NH}_{4}-\mathrm{N} \\
\cdot 5 \mathrm{~g}^{-1} \mathrm{dwt} \\
\mathrm{soil} \cdot 24 \mathrm{~h}^{-1}\end{array}$} & \multirow{2}{*}{$\begin{array}{l}\text { Dehydrogenase } \\
\text { activity } \\
\mu \mathrm{g} \mathrm{INTF} \cdot \mathrm{g}^{-1} \mathrm{dwt} \\
\text { soil } \cdot 2 \mathrm{~h}^{-1}\end{array}$} & \multirow{2}{*}{$\begin{array}{l}\mathrm{CO}_{2} \text { production } \\
\mathrm{mg} \mathrm{CO}_{2} \cdot 100 \mathrm{~g}^{-} \\
{ }^{1} \text { fwt soil } \\
\cdot 7 \text { day }^{-1}\end{array}$} \\
\hline & & $\begin{array}{l}\text { microscopic } \\
\text { fungi } \\
\times 10^{3} \mathrm{cfu} \cdot \mathrm{g}^{-1} \\
\mathrm{dwt} \text { soil }\end{array}$ & $\begin{array}{l}\text { aerobic cellulose } \\
\text { decomposing } \\
\text { bacteria } \times 10^{3} \mathrm{cfu} \cdot \\
\mathrm{g}^{-1} \text { dwt soil }\end{array}$ & & & & \\
\hline $\mathrm{W} 0-10 \mathrm{~cm}$ & 8.42 & 37.44 & 2.11 & 31.48 & 77.23 & 160.88 & 6.03 \\
\hline $\mathrm{W}^{*} 0-10 \mathrm{~cm}$ & 24.22 & 59.67 & 2.46 & 38.08 & 86.27 & 133.09 & 6.66 \\
\hline $\mathrm{V} 0-10 \mathrm{~cm}$ & 7.92 & 91.20 & 11.04 & 35.75 & 96.21 & 189.00 & 7.62 \\
\hline $\mathrm{V}^{*} 0-10 \mathrm{~cm}$ & 5.68 & 26.86 & 1.57 & 45.81 & 106.45 & 133.40 & 6.61 \\
\hline $\mathrm{W} 10-20 \mathrm{~cm}$ & 7.81 & 34.02 & 3.28 & 33.90 & 80.33 & 97.65 & 6.15 \\
\hline $\mathrm{W}^{*} 10-20 \mathrm{~cm}$ & 4.74 & 32.00 & 3.17 & 34.72 & 89.44 & 99.20 & 7.92 \\
\hline $\mathrm{V} 10-20 \mathrm{~cm}$ & 18.48 & 92.38 & 0.57 & 29.60 & 89.04 & 96.10 & 9.82 \\
\hline $\mathrm{V} * 10-20 \mathrm{~cm}$ & 4.13 & 58.02 & 0.35 & 26.03 & 144.64 & 96.75 & 7.70 \\
\hline LSD 5\% & 2.69 & 5.29 & 0.57 & 4.18 & 3.06 & 6.20 & 1.38 \\
\hline
\end{tabular}

W: wheat; $\mathrm{W}^{*}$ : wheat with deep loosing; V: vetch; $\mathrm{V}^{*}$ : vetch with deep loosing

The findings of conservation tillage can be summed up as follows (Table 2):

- Regarding the total numbers of bacteria and microscopic fungi, more colonies were cultured from the plots of vetch in both layers, and the differences were significant at 5\%-level. The fewest total bacteria were measured in the deeper layer of the wheat culture.

- Concerning the aerobic cellulose decomposing bacteria, there were no significant differences between the data from the two layers or between the two plant cultures. Only one result was salient, it was in the upper layer of vetch culture.

- As phosphatase, urease and dehydrogenase enzymes, higher biological activities were observed because in most cases the enzyme activities were significantly higher in the upper 0-10 cm layer than in the deeper layer, and significant differences were proven between the results at 5\% level. However, while phosphatase and urease activities were higher in the vetch culture, the dehydrogenase activities were similar in the upper layers. Dehydrogenase activity was only higher in the deeper layer of the vetch culture.

- Regarding $\mathrm{CO}_{2}$ production - similarly to the enzyme activities - significantly higher values were measured in the upper layers, except for one case. In the soil of vetch - in both layers - higher biological activities were observed where deep loosing was applied in every four years. 
Microbiological parameters in the conservational tillage plots of the long term experiment in Karcag Mean values of 2006

\begin{tabular}{|c|c|c|c|c|c|c|c|}
\hline \multirow[b]{2}{*}{ Sample } & \multirow{2}{*}{$\begin{array}{l}\text { Total } \\
\text { number of } \\
\text { bacteria } \\
\times 10^{6} \mathrm{cfu} \cdot \mathrm{g}^{-1} \\
\mathrm{dwt} \text { soil }\end{array}$} & \multicolumn{2}{|c|}{ Number of } & \multirow{2}{*}{$\begin{array}{l}\text { Phosphatase } \\
\text { activity } \\
\mathrm{mg} \mathrm{P}_{2} \mathrm{O}_{5} \cdot 5 \mathrm{~g}^{-} \\
{ }_{1} \mathrm{dwt} \text { soil. } \\
2 \mathrm{~h}^{-1}\end{array}$} & \multirow[b]{2}{*}{$\begin{array}{c}\text { Urease } \\
\text { activity } \\
\mathrm{mg} \mathrm{NH}_{4}-\mathrm{N} \\
\cdot 5 \mathrm{~g}^{-1} \mathrm{dwt} \\
\mathrm{soil} \cdot 24 \mathrm{~h}^{-1}\end{array}$} & \multirow{2}{*}{$\begin{array}{c}\text { Dehydrogenase } \\
\text { activity } \\
\mu \mathrm{g} \mathrm{INTF} \cdot \mathrm{g}^{-1} \mathrm{dwt} \text { soil } \\
\cdot 2 \mathrm{~h}^{-1}\end{array}$} & \multirow{2}{*}{$\begin{array}{l}\mathrm{CO}_{2} \text { production } \\
\mathrm{mg} \mathrm{CO}_{2} \cdot 100 \mathrm{~g}^{-1} \\
\text { fwt soil } \cdot 7 \text { day }^{-1}\end{array}$} \\
\hline & & $\begin{array}{l}\text { microscopic } \\
\text { fungi } \\
\times 10^{3} \mathrm{cfu} \cdot \mathrm{g}^{-1} \\
\text { dwt soil }\end{array}$ & $\begin{array}{l}\text { aerobic cellulose } \\
\text { decomposing } \\
\text { bacteria } \times 10^{3} \mathrm{cfu} . \\
\mathrm{g}^{-1} \mathrm{dwt} \text { soil }\end{array}$ & & & & \\
\hline $\mathrm{W} \mathrm{0-10} \mathrm{cm}$ & 7.64 & 42.00 & 6.48 & 31.25 & 129.44 & 312.00 & 12.17 \\
\hline $\mathrm{W}^{*} 0-10 \mathrm{~cm}$ & 11.80 & 45.43 & 4.13 & 31.75 & 96.51 & 315.65 & 14.08 \\
\hline $\mathrm{V} 0-10 \mathrm{~cm}$ & 24.81 & 107.37 & 4.24 & 49.36 & 126.24 & 184.53 & 7.29 \\
\hline $\mathrm{V}^{*} 0-10 \mathrm{~cm}$ & 13.38 & 61.20 & 42.00 & 39.58 & 212.52 & 322.50 & 10.61 \\
\hline W $10-20 \mathrm{~cm}$ & 20.41 & 49.77 & 6.80 & 24.88 & 104.68 & 79.50 & 10.46 \\
\hline $\mathrm{W}^{*} 10-20 \mathrm{~cm}$ & 3.39 & 59.22 & 1.64 & 29.80 & 66.94 & 56.70 & 10.12 \\
\hline V $10-20 \mathrm{~cm}$ & 27.44 & 78.75 & 4.38 & 31.47 & 113.10 & 109.38 & 5.15 \\
\hline $\mathrm{V}^{*} 10-20 \mathrm{~cm}$ & 19.82 & 140.63 & 1.63 & 38.52 & 103.85 & 79.56 & 14.58 \\
\hline LSD 5\% & 3,25 & 13.76 & 4.04 & 5.14 & 8.13 & 10.48 & 0.56 \\
\hline
\end{tabular}

$\mathrm{W}$ : wheat; $\mathrm{W}^{*}$ : wheat with deep loosing; V: vetch; $\mathrm{V}^{*}$ : vetch with deep loosing

Comparing the results of the two cultivation methods, the following can be stated:

- Generally, conservation tillage was more favourable for the microorganisms because the total number of bacteria, the numbers of microscopic fungi and aerobic cellulose decomposing bacteria were usually higher in the plots of both plants in 0-10 cm and 10-20 cm depths of soil, except for the values of the upper layer in the wheat culture of TP.

- There were no considerable differences between the results of phosphatase activities in the two cultivation methods. In certain cases, the traditional ploughing was more favourable, but in some other cases the conservation tillage proved to be a better cultivation method for this enzyme.

- The activities of urease and dehydrogenase enzymes (Figure 1) were significantly higher in the parcels of conservation tillage, especially in the upper 0-10 cm layer. Regarding dehydrogenase activity, its increase was between $93 \%-142 \%$, while in the case of urease, it was between $11 \%-102 \%$. In the deeper layer the dehydrogenase generally showed weaker activity in the treatments of conservation tillage.

Comparison of the effects of traditional ploughing and conservation tillage on dehydrogenase activity

Figure 1

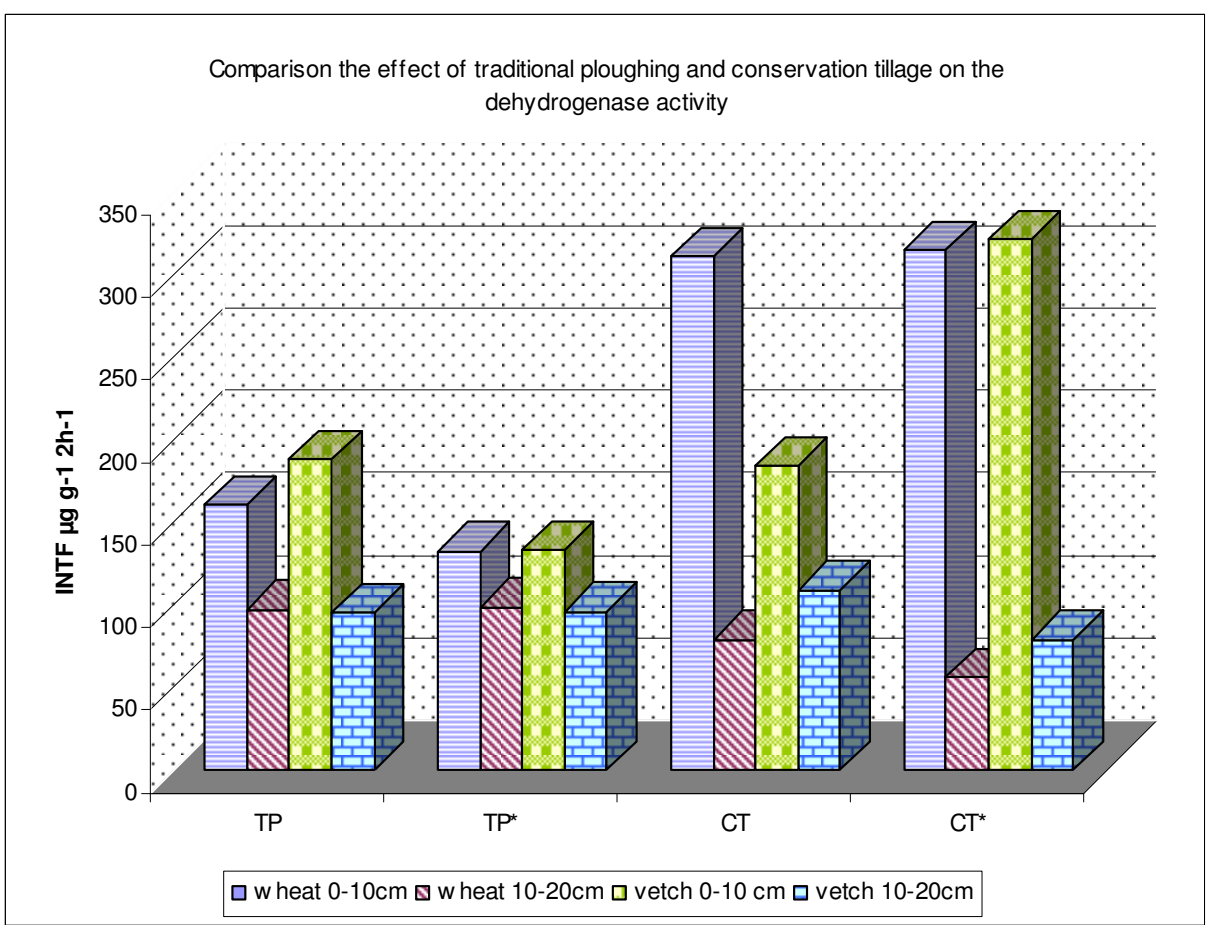

TP: traditional ploughing, TP* traditional ploughing with deep loosing, CT: conservational tillage, CT*: conservational tillage with deep loosing

- $\mathrm{CO}_{2}$ production was higher (Figure 2) in both layers of conservation tillage in both plant cultures, except for one case, namely in the $10-20 \mathrm{~cm}$ layer of the vetch plant soil. In the $0-10 \mathrm{~cm}$ layer this increase was between $60.5 \%-111 \%$, while in the deeper layer it was $27.7 \%-89 \%$. 


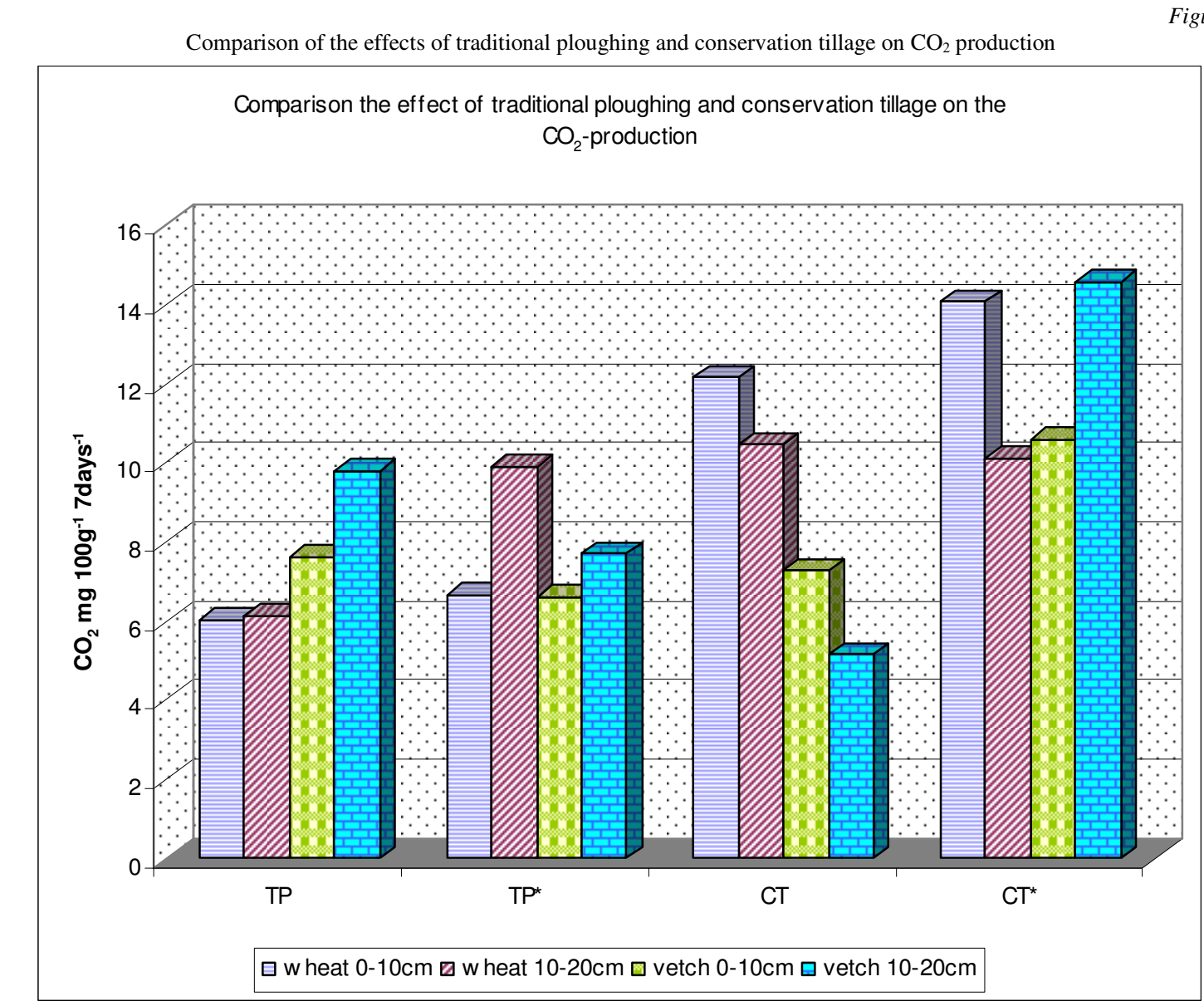

TP: traditional ploughing, TP* traditional ploughing with deep loosing, CT: conservational tillage, $\mathrm{CT}^{*}$ : conservational tillage with deep loosing

\section{CONCLUSION}

In a meadow chernozem soil the soil biological results of two cultivation methods were compared within a long-term experiment. The investigation took place under winter wheat (Triticum aestivum L.) and vetch (Vicia sativa L.) plant cultures. Summing up the results of the ninth year of the experiment, it can be stated that conservation tillage seemed to be a more favourable cultivation method for the majority of microorganisms and the activities of urease and dehydrogenase enzymes examined, especially in the upper layer of the soil. The activity of urease enzyme increased by $11 \%-102 \%$ and the dehydrogenase by $93 \%-142 \%$ in the upper layer of conservation tillage. It is important to note the significant increase of $\mathrm{CO}_{2}$ production in both layers examined. Concerning the plant cultures, the majority of microbiological parameters were higher in the soil of vetch depending on the cultivation methods. So involving pulses to the crop-rotation is important in this soil type.

The results indicated the importance of conservation tillage as a means of increasing soil biological activity in meadow chernozem soil (Vertisols). There was no significant effect of deep loosing applied in either cultivation methods on the quantities of bacteria and fungi.

Our results highlight the importance of measuring soil biological activity, beside chemical, physical and other ecological types of examination. The research of soil biological activity could provide an approximate answer to the anthropogenic and ecological effects.

\section{REFERENCES}

Carter, M. R. (1986): Microbial biomass as an index for tillage induced changes in soil biological properties. . Soil and Tillage Research. 7. 29-40.p.

Dick, R. P. (1992): A review: long-term effects of agricultural systems on soil biochemical and microbial parameters. Agric. Ecosys. Environment. 40. 25-36.p.

Donahue, R. L.,- Miller, R. W., - Shsickluna, J. C. (1983): Soils. An introduction to soils and plant growth. Prentice-Hall, Inc., Englewood Cliffs, New Jersey 07632. 77-81.p.

Filep Gy. 1995. Talajvizsgálat. (Egyetemi jegyzet) Debrecen, 32-56., 68-71; 93-96., 105-107 p.

Gerei L. (szerk.) 1970. Talajtani és agrokémiai vizsgálati módszerek. OMMI kiadvány. 19-17. p. 
Green, V.S.-Stott, D.E.-Cruz, J.C.-Curi, N. (2007): Tillage impacts on soil biological activity and aggregation in a Brazilian Cerrado Oxisol. Soil and Tillage Research Vol. 92, Issues 1-2, 114-121.p.

Grego, SBenedetti, A.,- Dell-Orco, S., -Rossi, G., -Marinari, S.,- Badalucco, L. (1996): Agricultural practices and biological activity in soil. Fresenius -Environmental-Bulletin. 5-6. 282-288.p.

Larson, W. E., Walsh L. M., Stewart B. A. \& Boelter D. H. (1981):Soil and Water Resources: Research Priorities for the Nation. Soil Science Society of America, Madison.

Jenkinson, D. S. \& Powlson, D. S., 1976. The effect of biocidal treatments on metabolism in soil. A method for measuring soil biomass. Soil Biol. Biochem. 27/8, 209-213. p.

Kandeler E.- Murer, E. (1993): Aggregate stability and soil microbial processes in a soil with different cultivation. Geoderma. 1993, 56. International Workshop, Wageningen.

Kennedy, A.C. \& Papedick, R. I. (1995): Microbial characteristics of soil quality. J. Soil Water Conserv. 50. 243-248.p.

Mersi, W. (1996): Dehidrogenase Activity with the Substrate INT In: Schinner, F. - Öhlinger, R. - Kandeler, E. - Margesin, R. Methods in soil biology. Springer-Verlag Berlin Heidelberg. 243-245.

Noble, A. D. - Gillmann, G. P. \& Ruaysoongnern, S., 2000. A cation exchange index for assessing degradation of acid soil by further acidification under permanent agriculture in the tropics. European Journal of Soil Science. 51, 233-243. p.

Pochon, J. \& Tardieux, P., 1962. Tecniques D’ Analyse en Micobiologie du Sol. Collection „Technivues de Base”. Masson co. Paris. 102. p.

Powlson, D. S., Brookers, P. C. \& Christensen, B. T. (1987): Measurement of soil microbial biomass provides an early indication of changes in total soil organic matter due to straw incorporation. Soil Biol. Biochem. 19. 159-164.p.

Rampazzo, N., Rajkai K., Blum-Weh, Várallyay, GY., Ubleis, T. (1999): Effects of long-term land use on soil properties along the Austrian-Hungarian border. International-Agrophysics. 13:2171-183.p.

Roldan, A.-Salinas-Garcia, J.R.-Alguacil, M.M.-Caravaca, F. (2007): Soil sustainability following conservation tillage practices under subtropical maize and bean crops. Soil \& Tillage Research Vol. 93. Issue 2. 273-282.p.

Roldan, A.-Salinas-Garcia, J.R.-Alguacil, M.M.-Diaz, E.-Caravaca, F. (2005): Soil enzymes activities suggest advantages of conservation tillage practices in sorghum cultivation under subtropical conditions. Geoderma. Vol.129. Issue:3-4. 178-185.p.

Samuel, A.D.-Domuta, C.-Ciobanu, C.- Sandor, M. (2008) : Field management effects on soil enzyme activities. Romanian Agricultural Research. Vol. 25. 61-68.p.

Singh, G. - Marwaha, T.S. - Kumar, D. (2009): Effect of source-conserving techniques on soil microbiological parameters under longterm maize (Zea mays) - wheat (Triticum aestivum) crop rotation. Indian Journal of Agricultural Sciences. Vol.:79, Issues:2, 94-100.p.

Szegi J., 1979. Talajmikrobiológiai vizsgálati módszerek. Mezőgazdasági Kiadó, Budapest. 250-256. p.

Usman, A. - Kuzyakov, Y. \& Stahr, K., 2005. Effect of clay minerals on immobilization of heavy metals and microbial activity in a sewage sludge-contaminated soil. Journal of soils and sediments. Vol. 5. Iss. 4. 245-252. p.

Witkamp, M, 1966. Decomposition of leaf litter in relation to environment microflora and microbial respiration. Ecology, 47. 194-201. p. 